\title{
Blood carbonic anhydrase activity in the newborn
}

\author{
ROBERT W. LOGAN, SHEILA M. CROOKS, JAMES H. HUTCHISON, \\ and MARGARET M. KERR \\ From the University Department of Child Health and Department of Biochemistry, \\ Queen Mother's Hospital, Glasgow
}

\begin{abstract}
Logan, R. W., Crooks, S. M., Hutchison, J. H., and Kerr, M. M. (1973). Archives of Disease in Childhood, 48, 256. Blood carbonic anhydrase activity in the newborn. Erythrocyte carbonic anhydrase activity was measured in 7 adults, 12 mature newborn infants, 12 preterm low birthweight infants, 9 'dysmature' infants, 33 infants with the respiratory distress syndrome (RDS), and 5 infants who had received intrauterine transfusions. The mean level of enzyme activity in infants with RDS was $3.6 \%$ of normal adult level, $21 \%$ of the mean level in mature infants, and $30 \%$ of the mean level in dysmature infants. There was, however, no significant difference between the mean enzyme activity found in infants with RDS and in low birthweight, preterm infants without RDS. In 3 of the 5 infants treated by intrauterine transfusion RDS developed while the carbonic anhydrase activity was up to adult levels. It is unlikely that the very low enzyme levels found in premature infants have any aetiological relation to the development of RDS, and there is no indication for treatment by exchange transfusion.
\end{abstract}

Carbonic anhydrase is a zinc-containing enzyme which catalyses the conversion of bicarbonate to carbon dioxide and water, or the reverse. It has been shown that there is a markedly reduced level of activity of this enzyme in the blood of infants with the respiratory distress syndrome (RDS) (Kleinman, Petering, and Sutherland, 1967), and it has been suggested that this might be related to the aetiology of this disease. The study of Poblete, Thibeault, and Auld (1968) has shown that in premature and term infants, the $\mathrm{CO}_{2}$ gradients existing between alveoli and a systemic artery do not correlate with whole blood carbonic anhydrase activity. Precise interpretation of their results is rendered difficult, however, when consideration is given to such factors as the interval between birth and blood sampling, the relative time spent by blood in the pulmonary capillaries compared with the reminder of the circulation, ventilationperfusion abnormalities, pulmonary diffusion defects, and the absolute carbonic anhydrase activity. It could reasonably be expected that within certain limits there would be an inverse relation between carbonic anhydrase activity and the $\mathrm{PCO}_{2}$ of blood in the pulmonary arteries which would not necessarily be reflected in blood returning to the systemic circulation. As it seemed

Received 28 July 1972. important to determine whether the low carbonic anhydrase activity in the blood of infants with RDS had any role in the pathogenesis of this disorder, a study was designed to measure the enzyme activity in various groups of neonates and to compare the levels with those found in healthy adults.

\section{Clinical material}

Carbonic anhydrase activity was measured in the packed cells from heparinized whole blood from 7 adult females, 12 preterm (not over 36 weeks' gestation) infants with birthweights below $2.5 \mathrm{~kg}$ (550 to $2290 \mathrm{~g}$ ), 12 mature infants (over 38 weeks' gestation), 9 'dysmature' infants whose birthweights fell below the 10th centile on the Denver intrauterine growth chart (Lubchenco, Hansman, and Boyd, 1966), 33 infants with typical RDS (birthweight over $2.5 \mathrm{~kg}$ in 2 cases only), and 5 infants who had received intrauterine transfusions for haemolytic disease of the newborn ( 3 with RDS, 2 without).

\section{Methods}

The blood was obtained from the umbilical vein or artery when catheterization was performed for therapy or monitoring of the blood gases in infants with RDS or haemolytic disease. In the other infants (mature, healthy, premature, and dysmature) the blood was obtained by heel stab or venepuncture when other routine tests (e.g. blood glucose, Dextrostix, serum bilirubin) were being performed. Most specimens were 
TABLE I

Comparison of carbonic anhydrase activities (Wilcoxon)

\begin{tabular}{|c|c|c|c|c|c|c|c|}
\hline & & $\begin{array}{c}\text { Carbonic anhydrase activity } \\
\text { mean value } \\
\text { (units/ml packed cells) }\end{array}$ & (A) & (B) & (C) & (D) & (E) \\
\hline $\begin{array}{l}\text { Adults } \\
\text { Mature infants } \\
\text { Dysmature infants } \\
\text { Premature infants nonRDS } \\
\text { RDS infants }\end{array}$ & $\begin{array}{l}\text { (A) } \\
\text { (B) } \\
\text { (D) } \\
\text { (E) }\end{array}$ & $\begin{array}{r}23,809 \\
4086 \\
2781 \\
1071 \\
848\end{array}$ & $\mathbf{x}$ & $\underset{\mathrm{x}}{<<0.01}$ & $\begin{array}{l}<<0.01 \\
<0.05 \\
\quad \mathrm{X}\end{array}$ & $\begin{aligned}< & <0.01 \\
& <0.01 \\
& <0.01 \\
& \mathbf{X}\end{aligned}$ & $\begin{aligned}< & <0.01 \\
& <0.01 \\
& <0.01 \\
& <0.1 \\
& \mathbf{X}\end{aligned}$ \\
\hline
\end{tabular}

obtained within 24 hours of birth. It was appreciated that as carbonic anhydrase is confined to the red cells, the variable haematocrit levels of our specimens might distort the findings to some extent, and to obviate this possible source of error results in all cases were expressed per ml packed cells. On the other hand, Kleinman et al. (1967) found no significant differences in the enzyme activity in blood obtained from umbilical artery, vein, or heel capillaries.

A colorimetric technique was employed for the determination of carbonic anhydrase activity. This was based on the procedures described by Roughton and Booth (1946) and Wilbur and Anderson (1948), and later modified by Kleinman et al. (1967).

Enzyme activity was measured on the basis of a $p \mathrm{H}-$ dependent colour change occurring as $\mathrm{CO}_{2}$ is hydrated to bicarbonate and hydrogen ions in the presence of veronal buffer and bromthymol blue. All experiments were performed in a Grant water bath with cooling coil, temperature being maintained at $3^{\circ} \mathrm{C}$. Temperature control was found to be critical since calculation of enzyme results was affected by applying the formula used by Kleinman et al. (1967).

$$
\text { Enzyme activity }=\frac{T_{0}-T}{T} \times \frac{1}{C}
$$

where $T_{0}=$ Time (in seconds) for uncatalysed reaction

$T=$ Time (in seconds) for enzymecatalysed reaction

C $=$ Dilution of packed cells

This formula is valid only where $T_{0}$ is constant since enzyme activity is actually proportional to $\left(1 / \mathrm{T}-1 / \mathrm{T}_{\mathrm{o}}\right)$ $\times 1 / \mathrm{C}$,

$$
\text { i.e. } \begin{aligned}
& \frac{1}{T_{0}}\left(\frac{T_{0}-T}{T}\right) \times \frac{1}{C} \\
= & \left(\frac{T_{0}-T}{T}\right) \times \frac{1}{C} \text { if } T_{0} \text { is constant. }
\end{aligned}
$$

Appropriate dilutions of suitably prepared haemolysates were made to yield ' $T$ ' values approximately half those of the $T_{o}$ value obtaining. By ensuring constancy of buffer strength and $\mathrm{pH}$ values, and by maintaining temperature at $3^{\circ} \mathrm{C}$, it was possible to ensure that the time required $\left(\mathbf{T}_{0}\right)$ for an uncatalysed reaction involving a change in $p \mathrm{H}$ from $8 \cdot 15$ to 6.3 was 200 seconds \pm 10 seconds. In these circumstances no correction for change in $T_{0}$ was made when calculating carbonic anhydrase activities.

\section{Results}

In the Fig. are shown the enzyme activities found in the various groups except those cases requiring intrauterine transfusion.

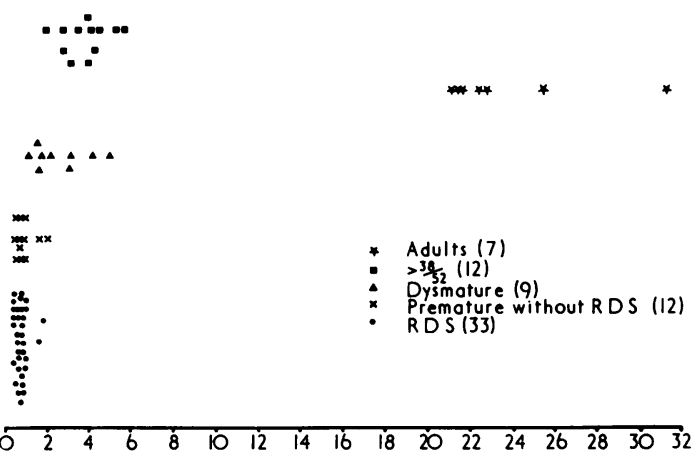

Units $\left(x, \frac{1}{10} 3\right)$ per $100 \mathrm{ml}$ packed cell

FIG.-Carbonic anhydrase activities in adults, term infants, dysmature infants, and preterm infants with and without respiratory distress syndrome.

Table I shows both the mean values of carbonic anhydrase activity for each group and the probability that differences between these groups occurred by chance. As can be seen, there is a high probability that the groups are significantly different with respect to their enzyme activities, though the premature infants without RDS and those exhibiting RDS did not differ at the 5\% level of significance.

Table II lists details including individual carbonic

TABLE II

Intrauterine transfusion cases

\begin{tabular}{c|c|c|c|l}
\hline $\begin{array}{c}\text { Case } \\
\text { no. }\end{array}$ & $\begin{array}{c}\text { Carbonic anhydrase } \\
\text { activity (units/ml } \\
\text { packed cells) }\end{array}$ & $\begin{array}{c}\text { Birthweight } \\
\text { (kg) }\end{array}$ & $\begin{array}{c}\text { Maturity } \\
\text { (wk) }\end{array}$ & $\begin{array}{c}\text { Clinical } \\
\text { outcome }\end{array}$ \\
\hline 1 & 21,740 & $2 \cdot 04$ & 33 & RDS \\
2 & 23,260 & $2 \cdot 75$ & 36 & RDS \\
3 & 29,400 & $1 \cdot 95$ & 33 & No RDS \\
4 & 14,600 & $2 \cdot 98$ & 38 & No RDS \\
5 & 25,000 & $2 \cdot 14$ & 34 & RDS \\
\hline
\end{tabular}


anhydrase activities for the cases which received one or more intrauterine transfusions.

\section{Discussion}

It is obvious that all newborn infants have carbonic anhydrase activities much below the levels found in the blood of healthy adults. There is presumably a critical level of enzyme activity below which $\mathrm{CO}_{2}$ cannot be eliminated from the lungs effectively because of the slowed conversion of bicarbonate, and in our infants with RDS the mean level of enzyme activity was only $3.6 \%$ of normal adult level and $21 \%$ of the mean level found in mature newborn infants. On the other hand, it was $30 \%$ of the enzyme activity found in our 'small-for-dates' infants, none of whom showed respiratory distress, and the mean enzyme activity of preterm infants with RDS (848 units/ $\mathrm{ml}$ ) was not statistically significantly different from the mean enzyme activity found in premature infants without respiratory distress (1071 units $/ \mathrm{ml}$ ). It is, therefore, extremely unlikely that the very low levels of carbonic anhydrase activity in infants with RDS had any aetiological significance. This is compatible also with the recent finding that the absence of surfactant from the lungs and the probable development of RDS postnatally can be forecast before birth from measurement of the lecithin/sphingomyelin ratio in the liquor amnii obtained by amniocentesis (Gluck et al., 1971; Whitfield et al., 1972). However, deficiency of carbonic anhydrase activity in infants suffering from $\mathrm{RDS}$ and consequent $\mathrm{CO}_{2}$ retention may worsen an already serious situation by inhibiting the conversion of bicarbonate to $\mathrm{CO}_{2}$, so that diffusion of $\mathrm{CO}_{2}$ out of the pulmonary capillaries will not be satisfactory during the rapid passage of the blood through the lungs. In common with others, we have sometimes had the impression that exchange transfusion for haemolytic disease in infants who also suffered from RDS had a beneficial effect on the respiratory disorder. 4 of the 33 infants who suffered from RDS had rhesus incompatibility of a degree requiring exchange transfusion. 3 died despite intensive care, including ventilation. The respiratory problem did not appear to improve during transfusion. The fourth infant (birthweight $2730 \mathrm{~g}$ at 36 weeks' gestation) tolerated the procedure of transfusion well. In 3 of the 5 infants treated by intrauterine transfusion and who also suffered from severe RDS (fatal in 2 cases), the carbonic anhydrase activity was up to normal adult levels. It seems, therefore, that, like so many other physiological measurements, the carbonic anhydrase levels in the newborn infant differ from those of the adult, and raising the enzyme activity in the preterm infant with RDS by exchange transfusion is unlikely to prove of much benefit.

The authors thank W. P. Barnard, of the Department of Biochemistry, for the statistical evaluation.

\section{REFERENCES}

Gluck, J., Kulovich, M. V., Borer, R. C., Brenner, P. H., Anderson, G. G., and Spellacy, W. N. (1971). Diagnosis of the respiratory distress syndrome by amniocentesis. American fournal of Obstetrics and Gynecology, 109, 440.

Kleinman, L. I., Petering, H. G., and Sutherland, J. M. (1967). Blood carbonic anhydrase activity and zinc concentration in infants with respiratory-distress syndrome. New England Fournal of Medicine, 277, 1157.

Lubchenco, L. O., Hansman, C., and Boyd, E. (1966). Intrauterine growth in length and head circumference as estimated from live births at gestational ages from 26 to 42 weeks. Pediatrics, 37, 403.

Poblete, E., Thibeault, D. W., and Auld, P. A. M. (1968). Carbonic anhydrase in the premature. Pediatrics, 42, 429.

Roughton, F. J. W., and Booth, V. H. (1946). The effect of substrate concentration, $\mathrm{pH}$ and other factors upon the activity of carbonic anhydrase. Biochemical fournal, 40, 319.

Whitfield, C. R., Chan, W. H., Sproule, W. B., and Stewart, A. D. (1972). Amniotic fluid lecithin : sphingomyelin ratio and fetal lung development. British Medical fournal, $2,85$.

Wilbur, K. M., and Anderson, N. G. (1948). Electrometric and colorimetric determination of carbonic anhydrase. Fournal of Biological Chemistry, 176, 147.

Correspondence to Dr. Robert W. Logan, Department of Biochemistry, Queen Mother's Hospital, Glasgow G3 8SH. 